\title{
The influence of $\alpha$-aminophosphonic acids on the activity of aminopeptidase from barley seeds-an approach to determine the enzyme specificity
}

\author{
Bartosz Oszywa $\cdot$ Małgorzata Pawełczak • \\ Paweł Kafarski
}

Received: 30 September 2014/Revised: 22 January 2015/ Accepted: 22 January 2015/Published online: 12 February 2015

(C) The Author(s) 2015. This article is published with open access at Springerlink.com

\begin{abstract}
Inhibitory potencies of $24 \alpha$-aminophosphonic acids against barley seeds (Hordeum vulgare L.) metalloaminopeptidase have been determined to evaluate structural requirements of this enzyme. The enzyme was sensitive mostly to the influence of phosphonic acid analogues of phenylalanine and its homologues, thus showing narrow specificity if compared with porcine aminopeptidases M1 and M17 and with Plasmodium aminopeptidase M17.
\end{abstract}

Keywords $\alpha$-Aminophosphonic acids · Aminopeptidase . Barley seeds · Inhibitors

\section{Introduction}

The aminopeptidases (EC 3.4.11) according to IUBMB classification belong to the class of hydrolase, subclasses of peptidase, and sub-subclass of aminopeptidases. They have capacity to remove individual amino acids from the

Communicated by G. Klobus.

B. Oszywa · M. Pawełczak $(\bowtie) \cdot$ P. Kafarski

Faculty of Chemistry, University of Opole, ul. Oleska 48, 45-052 Opole, Poland

e-mail: Malgorzata.Pawelczak@uni.opole.pl

B. Oszywa

e-mail: bartosz.oszywa@pwr.wroc.pl

P. Kafarski

e-mail: pawel.kafarski@pwr.wroc.pl

P. Kafarski

Department of Bioorganic Chemistry, Faculty of Chemistry, Wrocław University of Technology, Wybrzeże Wyspiańskiego 27, 50-370 Wrocław, Poland
N-terminus of protein substrates (Lowther and Matthews 2002; Taylor 1993).

The aminopeptidase enzymes are commonly found in biological kingdoms (microorganisms, plants and animals) and can be located in the cytoplasm, or various types of membranes and cell organelles. These enzymes play a number of more or less important and characteristic functions. Together with other peptidases, they steer metabolic pathways, control the metabolism of proteins, and activate other enzymes and hormones necessary for the proper functioning of the body. The aminopeptidase due to the fact that they can recover the amino acids from dietary and endogenous proteins also has a nutritional function.

They are necessary for proper functioning of eukaryotic and prokaryotic cells, but often are also important factors in various pathological states and diseases such as: malaria, cancer, diabetes, HIV, cataracts, angiogenesis, hypertension, systemic lupus (Hooper and Lendeckel 2004; Sanderink et al. 1988; Sanz 2007; Jankiewicz and Bielawski 2003; Pulido-Cejudo et al. 1997; Taylor et al. 1982; Sharma et al. 1996; Inokuma et al. 1999; Umezawa 1980; Pretlow et al. 1994; Mathe 1991).

In plants, the high concentration of aminopeptidases has been found in the seeds, young fast-growing organs, the parts which have been injured or damaged, and in the old, dying plant parts. High levels of these enzymes have been observed in plants grown under harsh conditions, especially under osmotic stress, which is due to water shortage or too high salinity (Bartling and Weiler 1992; Desimone et al. 2000; Thayer et al. 1988; Matsui et al. 2006; Ogiwara et al. 2005; Chien et al. 2002). Therefore, they may be considered as an element of "immunological response" of plants (Fowler et al. 2009; Bae et al. 2013).

Phosphonic acids and their derivatives are acting as inhibitors of aminopeptidases. This results from that these 
compounds imitate the tetrahedral transition state of peptide bond hydrolysis. In these reactions, at least one intermediate, in which the carbon atom participating in the reaction adopts the $\mathrm{sp}^{3}$ configuration, is formed. Since phosphonic moiety also has tetrahedral structure and is mimicking this state, phosphonates exhibit inhibitory action towards proteolytic enzymes (Giannousis and Bartlett 1987; Dive et al. 2004; Lejczak et al. 1989; Mucha et al. 2008, 2010; Dragg et al. 2005). Thus, they might be used as tools for differentiating aminopeptidases from various sources and to determine the structural requirements for their N-terminal fragment binding.

The results of the studies on the activity of large libraries of fluorogenic substrates tailored to study proteolytic enzymes indicate enzyme preferences toward peptide side chance. In this manner, the sets of data that may be useful for design and synthesis of selective inhibitors are obtained (Drąg et al. 2010; Kasperkiewicz et al. 2012; Poras et al. 2011, 2013; Węglarz-Tomczak et al. 2013; Poręba et al. 2014).

In this paper, we examined the influence of simple $\alpha$-aminophosphonic acids on activity of novel metalloaminopeptidase isolated from seeds of barley (Oszywa et al. 2013) and compared the results with published data concerning porcine and Plasmodium aminopeptidases (Cunningham et al. 2008).

\section{Materials and methods}

\section{Plant materials}

Fresh seeds of barley were obtained from a local farmer and until use were stored at $4{ }^{\circ} \mathrm{C}$. Aminopeptidases from barley seeds were isolated and purified in accordance with the previous described procedure (Oszywa et al. 2013). The enzyme was purified in six stages. Purification methods: ammonium sulphate precipitation, gel chromatography (Sephadex G-25, Sephacryl HR 300), ion chromatography (DEAE-Sepharose, Macro-Prep Q) and hydrophobic interaction chromatography (PhenylSepharose HP). Purity of the isolated enzyme was determined by SDS-PAGE electrophoresis. The molecular weight of the enzyme calculated based on the gel filtration (Sephacryl HR 300) and SDS-PAGE electrophoresis was $58 \mathrm{kDa}$.

\section{Compounds}

Aminophosphonic acids were available from earlier studies (Lejczak et al. 1989; Drạg et al. 2005; Cunningham et al. 2008) or were synthesized according to the modified literature procedure (Soroka 1989).
Acetamide $(0.2 \mathrm{~mol})$ was dissolved in acetic acid $(40 \mathrm{ml})$ and cooled in an ice bath followed by addition of acetyl chloride $(0.1 \mathrm{~mol})$. This resulted in crystallization of unidentified by-product. After $15 \mathrm{~min}$, the appropriate aldehyde was introduced and the mixture was stirred in an ice bath for $30 \mathrm{~min}$. Mixture was allowed to stand for about a day at room temperature. The next day the mixture was cooled again in an ice bath, and then phosphorus trichloride $(0.1 \mathrm{~mol})$ was added in portions maintaining ice bath temperature for $30 \mathrm{~min}$. After warming to room temperature, the mixture was heated for $1 \mathrm{~h}$ at $70-75^{\circ} \mathrm{C}$ to complete the reaction. The volatile components of the reaction mixture were removed on rotary evaporator affording an oily product, which was then hydrolysed by refluxing in $100 \mathrm{ml}$ concentrated hydrochloric acid for $8 \mathrm{~h}$. After evaporation of water solution under reduced pressure, the oily product was dissolved in ethanol and left for a night to allow ammonium chloride and by-products (bisphosphonates) to precipitate (Dziuganowska et al. 2014). After filtration of these by-products, the desired aminophosphonate was crystallized from water/ethanol mixture.

\section{Enzyme assays}

Aminopeptidase activity was examined at $37{ }^{\circ} \mathrm{C}$ in $50 \mathrm{mM}$ Tris- $\mathrm{HCl}, \mathrm{pH} 7.5$ containing $\mathrm{NaCl}(50 \mathrm{mM})$ and 2-mercaptoethanol $(10 \mathrm{mM})$. Synthetic substrate L-leucine-p-nitroanilide (solution in DMSO) was added to the assay buffer and the solution was supplemented with the enzyme. The progress of the hydrolysis of L-Leu-pNA was monitored spectrophotometrically (UV-VIS Spectrophotometer Cintra 303) at a wavelength of $405 \mathrm{~nm}$ against a control sample lacking enzyme. The measured $K_{\mathrm{M}}$ value was $0.55 \mathrm{mM}$. The assay mixture, totally $1.15 \mathrm{ml}$, contained: solution of the synthetic substrate LLeu-pNA in DMSO (final concentration from 1.5 to $0.2 \mathrm{mM}$ ), $50 \mathrm{mM}$ Tris-HCl buffer (pH 7.5), containing $50 \mathrm{mM} \mathrm{NaCl}$, and $10 \mathrm{mM} \mathrm{2-mercaptoethanol,} \mathrm{the} \mathrm{solu-}$ tion of the potential inhibitor in reaction buffer (concentration of compound dependent on inhibitory activity), and enzyme ( $0.028 \mathrm{mg}$ of protein). The enzymatic reaction was performed at $37{ }^{\circ} \mathrm{C}$ for $15 \mathrm{~min}$.

Inhibition constants for the $\alpha$-aminophosphonic acids toward barley AP were determined basing on Lineweaver-Burk, Dixon, Hanes-Woolf curves and from a half-inhibitory concentration method for the reactions carried out in the presence of inhibitor and lacking an inhibitor. Reaction velocities were determined based on the progression curves (change in the absorbance over time). All reactions were carried out for four substrate concentrations and five concentrations of each inhibitor with each study being repeated three times. For each of 
the designated kinetic parameters, $V_{\mathrm{o}}, V_{\max }, K_{\mathrm{M}}$ and $K_{\mathrm{i}}$ were calculated relative error. The values given in the Table 1 are the average values of $K_{\mathrm{i}}$ calculated by all these methods. Scatter of results $\left(K_{\mathrm{i}}\right.$ values) did not exceed $10 \%$ for each of the test inhibitor.

\section{Results and discussion}

Nearly all the studied aminophosphonates appear to inhibit aminopeptidase from barley seeds (Table 1). All of them appeared to be competitive inhibitors (see representative
Table 1 Structures of studied $\alpha$-aminophosphonic acids and their inhibition constants $\left(K_{\mathrm{i}}\right)$ towards aminopeptidase from barley seeds

\begin{tabular}{|c|c|c|c|c|c|}
\hline Cpd. & Structure & $\begin{array}{c}\text { Inhibition } \\
\text { constant } K_{i} \\
{[\mu \mathrm{M}] \pm \mathrm{SD}}\end{array}$ & Cpd. & Structure & $\begin{array}{c}\text { Inhibition } \\
\text { constant } K_{i} \\
{[\mu \mathrm{M}] \pm \mathrm{SD}}\end{array}$ \\
\hline 1 & & $77 \pm 2$ & 2 & & $\begin{array}{c}\text { No inhibition } \\
\text { up to } \\
1.12 \mathrm{mM}\end{array}$ \\
\hline 3 & & $\begin{array}{c}\text { No inhibition } \\
\text { up to } \\
2.47 \mathrm{mM}\end{array}$ & 4 & & $\begin{array}{l}\text { No inhibition } \\
\text { up to } \\
2.90 \mathrm{mM}\end{array}$ \\
\hline 5 & & $2736 \pm 50$ & 6 & & $186 \pm 15$ \\
\hline 7 & & $1560 \pm 60$ & 8 & & $960 \pm 40$ \\
\hline 9 & & $850 \pm 40$ & 10 & & $1294 \pm 50$ \\
\hline 11 & & $316 \pm 12$ & 12 & & $367 \pm 20$ \\
\hline 13 & & $416 \pm 15$ & 14 & & $538 \pm 20$ \\
\hline 15 & & $150 \pm 8$ & 16 & & $255 \pm 5$ \\
\hline 17 & & $88 \pm 3$ & 18 & & $25 \pm 1$ \\
\hline 19 & & $28 \pm 1$ & 20 & & $164 \pm 8$ \\
\hline 21 & & $54 \pm 2$ & 22 & & $955 \pm 30$ \\
\hline 23 & & $505 \pm 10$ & 24 & & $330 \pm 15$ \\
\hline
\end{tabular}




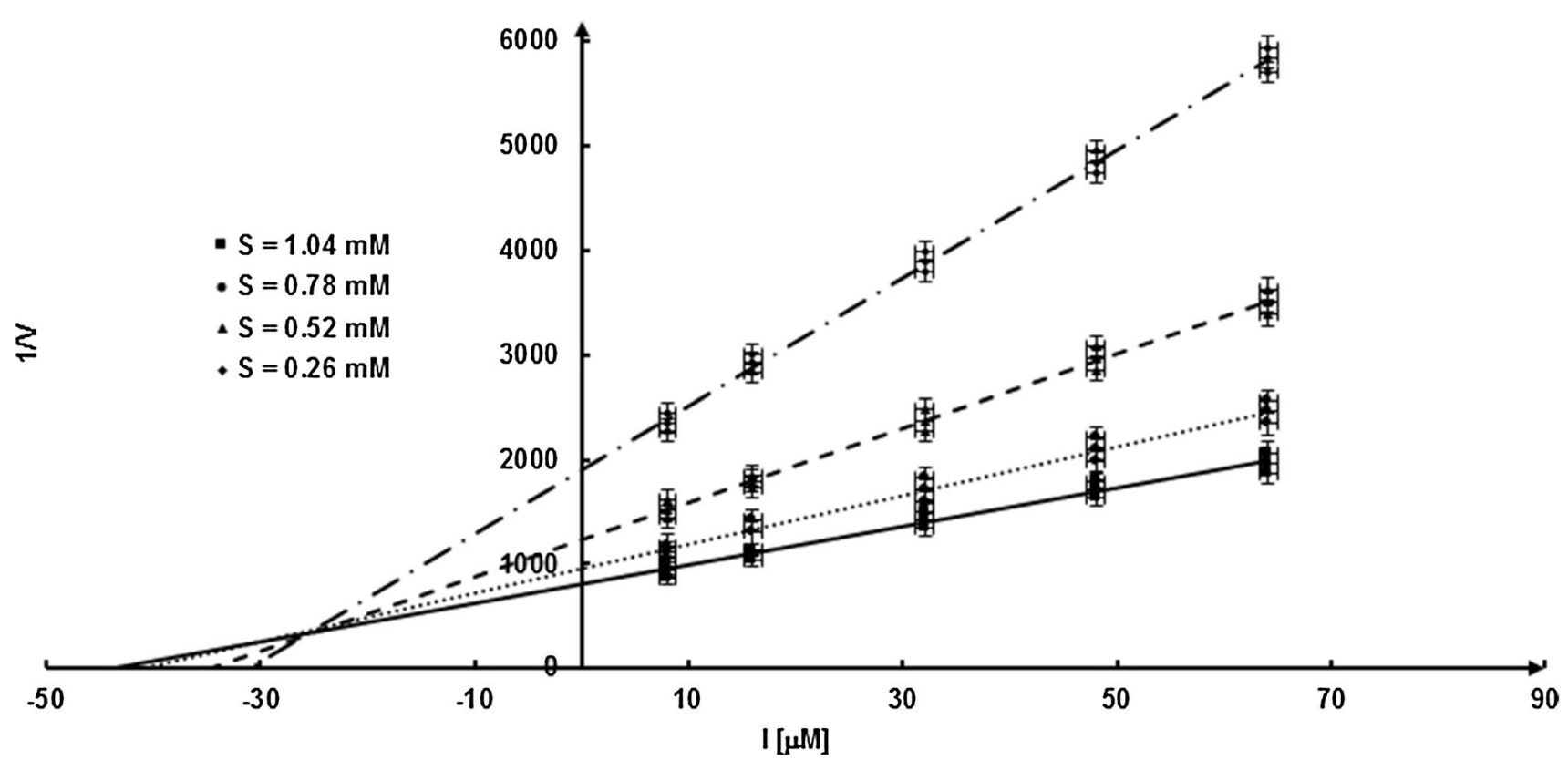

Fig. 1 The type designation inhibition and the inhibition constant $K_{\mathrm{i}}$ by Dixon method for the compound 1(RS)-amino-3-phenylpropanephosphonic acid towards aminopeptidase from barley seeds

Table 2 Comparison of inhibitory activity of $\alpha$ aminophosphonic acids to mammalian aminopeptidases

NI no inhibit enzyme activity

a Lejczak et al. (1989)

b Drąg et al. (2005)

\begin{tabular}{|c|c|c|c|c|}
\hline Cpd. & Stereomer & AP barley $K_{\mathrm{i}}(\mu \mathrm{M})$ & LAP porcine $K_{\mathrm{i}}(\mu \mathrm{M})^{\mathrm{b}}$ & APN porcine $K_{\mathrm{i}}(\mu \mathrm{M})^{\mathrm{b}}$ \\
\hline 1. & $1 \mathrm{R}$ & 77 & $0.23^{\mathrm{a}}$ & $53^{\mathrm{a}}$ \\
\hline 2. & RR:RS, 1:1 & $\mathrm{NI}$ & - & - \\
\hline 3. & $1 \mathrm{RS}$ & $\mathrm{NI}$ & 798 & NI \\
\hline 4. & $1 \mathrm{RS}$ & $\mathrm{NI}$ & - & - \\
\hline 5. & $1 \mathrm{R}$ & 2,736 & 243 & 138 \\
\hline 6. & $1 \mathrm{RS}$ & 186 & 33 & NI \\
\hline 7. & $1 \mathrm{RS}$ & 1,560 & $1^{\mathrm{a}}$ & $26.5^{\mathrm{a}}$ \\
\hline 8. & $1 \mathrm{RS}$ & 960 & - & - \\
\hline 9. & $1 \mathrm{RS}$ & 850 & 84.5 & 178 \\
\hline 10. & $1 \mathrm{RS}$ & 1,294 & 22.7 & 77.4 \\
\hline 11. & $1 \mathrm{RS}$ & 316 & 6.92 & 47.7 \\
\hline 12. & $1 \mathrm{RS}$ & 367 & 6.35 & 18.5 \\
\hline 13. & $1 \mathrm{R}$ & 416 & 7.89 & 161 \\
\hline 14. & $1 \mathrm{RS}$ & 538 & 0.75 & 54.7 \\
\hline 15. & $1 \mathrm{RS}$ & 150 & 0.21 & 37.1 \\
\hline 16. & $1 \mathrm{RS}$ & 255 & - & - \\
\hline 17. & $1 \mathrm{RS}$ & 88 & - & - \\
\hline 18. & $1 \mathrm{RS}$ & 25 & 0.14 & 15.9 \\
\hline 19. & $1 \mathrm{RS}$ & 28 & 0.26 & 36.9 \\
\hline 20. & $1 \mathrm{RS}$ & 164 & 0.33 & 3.69 \\
\hline 21. & $1 \mathrm{RS}$ & 54 & NI & 168 \\
\hline 22. & $1 \mathrm{RS}$ & 955 & 1.37 & NI \\
\hline 23. & $1 \mathrm{RS}$ & 505 & 0.33 & 170 \\
\hline 24. & 1RS & 330 & 0.12 & 23.7 \\
\hline
\end{tabular}


Fig. 1) and, in opposition to porcine aminopeptidase M17, slow-binding kinetics has not been observed. Analogues of aliphatic amino acids appeared to be weak or negligible inhibitors of the enzyme with phosphonic acid analogue of leucine (compound 1) being moderately active. Compounds bearing phenyl ring appeared to be far more active, with phosphonic acid analogue of homophenylalanine (compound 18) acting as the most effective one. Its homologue, compound 19, bearing an additional methyl at carbon atom in position 3 also exhibited a significant activity against this enzyme. A similar model of activity was observed for the porcine aminopeptidases (Table 2) and aminopeptidase from Plasmodium falciparum (value of $\mathrm{IC}_{50}$ for compound $\mathbf{1 8}$ is $22 \mu \mathrm{M}$; Cunningham et al. 2008). This, alongside with significant activity of compound $\mathbf{2 1}$, indicates that there is a spacious binding site able to accommodate hydrophobic N-terminal fragments of inhibitors. The activity of this particular compound is somewhat surprising since it appeared to be far less active towards porcine enzymes. This, alongside with significantly weaker activity of compound $\mathbf{2 0}$ and these carrying alkyl substituents, indicates that the part of the barley enzyme binding hydrophobic fragment of aminophosphonate inhibitors differs from those observed in the case of porcine and Plasmodium enzymes. This is also seen from introduction of hydrophilic moiety into phenyl ring (compounds 22, 23 and 24), which resulted in significant decrease in affinities of such compounds towards aminopeptidase from barley seeds, whereas these compounds exhibited quite pronounced action towards porcine and Plasmodium enzymes.

Thus, comparison of the patterns of inhibitory activities of barley enzyme with two porcine aminopeptidases M17 (LAP, EC 3.4.11.1) and M1 (APN, EC 3.4.11.2) (Lejczak et al. 1989; Drąg et al. 2005) indicates that aminopeptidase from barley seeds is quite different from the two bovine enzymes being nearly exclusively sensitive to the action of phosphonic acid analogues of phenylalanine (compounds 17-20) (Table 2). Aminopeptidase M17 prefers both aliphatic and aromatic hydrophobic aminophosphonates (compounds 18-20 and 1, 5 and 13; with analogues of leucine and homoalanine being of choice), whereas aminopeptidase M1 is preferably inhibited by aminophosphonates containing additional hydrophilic group in side chain, with analogue of homotyrosine (compound 24) being the most active. Although Plasmodium falciparum aminopeptidase M17 (EC 3.4.11.1) prefers aminophosphonates bearing hydrophobic aromatic moiety in their side chain (Cunningham et al. 2008), the pattern of activity against this enzyme is also quite different because it is not sensitive to compounds 10 13. Thus, our study indicates that the use of libraries of simple inhibitors could be a useful tool in determining specificities of aminopeptidases and their fingerprints.

\section{Conclusions}

$\alpha$-Aminophosphonic acids appeared to be moderate or weak inhibitors of newly isolated aminopeptidase from barley seeds. Its pattern of activity is significantly different from those found for structurally related aminopeptidases M17 from Plasmodium and bovine lens, as well as porcine M1 aminopeptidase. Although the plant enzyme is also metallopeptidase phosphonic acid, analogues of amino acids appeared to be significantly weaker inhibitors of the enzyme.

Author contribution statement Bartosz Oszywa: protocol execution, graphics, data collection, statistical analysis, partial writing of the paper. Małgorzata Pawełczak: conceptualization hypothesis, design of the research, publication search, mentorship and consultation, partial writing of the paper, paper revision prior to submission. Paweł Kafarski: synthesis compounds, data interpretation conclusions, writing the paper, mentorship and consultation, grant and funding acquisition. All the authors read corrected and approved the manuscript in its final form.

Acknowledgments The research was supported by Wroclaw Research Center EIT + under the project "Biotechnologies and advanced medical technologies-BioMed" (POIG 01.01.02-02-003/08-00 financed from the European Regional Development Fund (Operational Programme Innovative Economy, 1.1.2). Bartosz Oszywa is recipient of a Ph.D. fellowship from a project funded by the European Social Found.

Open Access This article is distributed under the terms of the Creative Commons Attribution License which permits any use, distribution, and reproduction in any medium, provided the original author(s) and the source are credited.

\section{References}

Bae C, Kim SM, Lee DJ, Choi D (2013) Multiple classes of immunerelated proteases associated with the cell death response in pepper plants. PLoS One 8:e63533

Bartling D, Weiler EW (1992) Leucine aminopeptidase from Arabidopsis thaliana. Eur J Biochem 205:425-431

Chien HCR, Lin LL, Chao SH, Chen CC, Wang WC, Sham CY, Tsai YC, Hu H, Hsu WH (2002) Purification, characterization, and genetic analysis of a leucine aminopeptidase from Aspergillus sojae. Biochim Biophys Acta 1576:119-126

Cunningham E, Drąg M, Kafarski P, Bell A (2008) Chemical target validation studies of aminopeptidase in malaria parasites using $\alpha$-aminoalkylphosphonate and phosphonopeptide inhibitors. Antimicrob Agents Chemother 52:3221-3228

Desimone M, Krüger M, Wessel T, Wehofsky M, Hoffmann R, Wagner E (2000) Purification and characterization of an aminopeptidase from the chloroplast stroma of barley leaves by chromatographic and electrophoretic methods. J Chromatogr B Biomed Sci Appl 737:285-293

Dive V, Georgiadis D, Matziari M, Makaritis A, Beau F, Cuniasse P, Yiotakis A (2004) Phosphinic peptides as zinc metalloproteinase inhibitors. CMLS 61:2010-2019 
Drąg M, Grembecka J, Pawełczak M, Kafarski P (2005) $\alpha$ Aminoalkylphosphonates as a tool in experimental optimization of P1 side chain shape of potential inhibitors in S1 pocket of leucine and neutral aminopeptidases. Eur $\mathrm{J}$ Med Chem 40:764-771

Drąg M, Bogyo M, Ellman JA, Salvesen GS (2010) Aminopeptidase fingerprints. An integrated approach for identification of good substrates and optimal inhibitors. J Biol Chem 285:3310-3318

Dziuganowska Z, Andrasiak I, Ślepokura K, Kafarski P (2014) Amidoalkylation of phosphorus trichloride with acetamide and functionalized cyclic ketones-evidence of dominating role of side-reactions. Phosphorus Sulfur Silicon Relat Elem 189:1-8

Fowler JH, Návaes-Vásques J, Aromdee DN, Pautot V, Holzer FM, Walling LL (2009) Leucine aminopeptidase regulates defense and wound signaling in tomato downstream of jasmonic acid. Plant Cell 21:1239-1251

Giannousis PP, Bartlett PA (1987) Phosphorus amino acid analogues as inhibitors of leucine aminopeptidase. J Med Chem 30:1603-1609

Hooper NM, Lendeckel U (eds) (2004) Aminopeptidases in biology and disease, proteases in biology and disease, vol 2. Kluwer Academic/Plenum, New York

Inokuma S, Setoguchi K, Ohta T, Matsuzaki Y, Yoshida A (1999) Serum leucine aminopeptidase as an activity indicator in systemic lupus erythematosus: a study of 46 consecutive cases. Rheumatol (Oxf) 38:705-708

Jankiewicz U, Bielawski W (2003) The properties and functions of bacterial aminopeptidases. Acta Microbiol Pol 52:217-231

Kasperkiewicz P, Gajda AD, Drąg M (2012) Current and prospective applications of non-proteinogenic amino acids in profiling of proteases substrate specificity. Biol Chem 393:843-851

Lejczak B, Kafarski P, Zygmunt J (1989) Inhibition of aminopeptidases by aminophosphonates. Biochemistry 28:3549-3555

Lowther WT, Matthews BW (2002) Metalloaminopeptidases: common functional themes in disparate structural surroundings. Chem Rev 102:4581-4608

Mathe G (1991) Bestatin, an aminopeptidase inhibitor with a multipharmacological function. Biomed Pharmacother 45:49-54

Matsui M, Fowler JH, Walling LL (2006) Leucine aminopeptidases: diversity in structure and function. Biol Chem 387:1535-1544

Mucha A, Lämmerhofer M, Lindner W, Pawełczak M, Kafarski P (2008) Individual stereoisomers of phosphinic dipeptide inhibitor of leucine aminopeptidase. Bioorg Med Chem Lett 18:1550-1554

Mucha A, Drag M, Dalton JP, Kafarski P (2010) Metallo-aminopeptidase inhibitors. Biochimie 92:1509-1529

Ogiwara N, Amano T, Satoh M, Shioi Y (2005) Leucine aminopeptidase from etiolated barley seedlings: characterization and partial purification of isoforms. Plant Sci 168:575-581
Oszywa B, Makowski M, Pawełczak M (2013) Purification and partial characterization of Aminopeptidase from barley (Hordeum vulgare L.) seeds. Plant Physiol Biochem 65:75-80

Poras H, Ouimet T, Orng S-V, Dangé E, Fournié-Zaluski MC, Roques BP (2011) Pluripotentialities of a quenched fluorescent peptide substrate library: enzymatic detection, characterization, and isoenzymes differentiation. Anal Biochem 419:95-105

Poras H, Duquesnoy S, Fournié-Zaluski MC, Ratinaud-Giraud C, Roques BP, Ouimet T (2013) A sensitive fluorigenic substrate for selective in vitro and in vivo assay of leukotriene A4 hydrolase activity. Anal Biochem 441:152-161

Poręba M, Mihelic M, Krai P, Rajkovic J, Krężel A, Pawełczak M, Klemba M, Turk D, Turk B, Latajka R, Drạg M (2014) Unnatural amino acids increase activity and specificity of synthetic substrates for human and malarial cathepsin C. Amino Acids 46:931-943

Pretlow TG, Nagabhushan M, Sy M, Guo Y, Pretlow TPJ (1994) Putative preneoplastic foci in the human prostate. Cell Biochem Suppl 19:224-231

Pulido-Cejudo G, Conway B, Proulx P, Brown R, Izaguirre CA (1997) Bestatin-mediated inhibition of leucine aminopeptidase may hinder HIV infection. Antiviral Res 36:167-177

Sanderink GJ, Artur Y, Siest G (1988) Human aminopeptidases: a review of the literature. J Clin Chem Clin Biochem 26:795-807

Sanz Y (2007) Aminopeptidases. In: Polaina J, MacCabe AP (eds) Industrial enzymes, Springer, Heidelberg, pp 243-260

Sharma KK, Elser NJ, Kester K (1996) Comparison of leucine aminopeptidase and aminopeptidase III activities in lens. Curr Eye Res 15:774-781

Soroka M (1989) Comments on the synthesis of aminomethylphosphonic acid. Synthesis 7:547-548

Taylor A (1993) Aminopeptidases: structure and function. FASEB J 7:290-298

Taylor A, Daims M, Lee J, Surgenor T (1982) Identification and quantification of leucine aminopeptidase in aged normal and cataractous human lenses and ability of bovine lens LAP to cleave bovine crystallins. Curr Eye Res 2:47-56

Thayer SS, Choe HT, Rausser S, Huffaker RC (1988) Characterization and subcellular localization of aminopeptidases in senescing barley leaves. Plant Physiol 87:894-897

Umezawa H (1980) Screening of small molecular microbial products modulating immune responses and bestatin. Recent Results Cancer Res 40:115-125

Węglarz-Tomczak E, Poręba M, Byzia A, Berlicki Ł, Nocek B, Mulligan R, Joachimiak A, Drąg M, Mucha A (2013) An integrated approach to the ligand binding specificity of Neisseria meningitidis M1 alanine aminopeptidase by fluorogenic substrate profiling, inhibitory studies and molecular modeling. Biochimie 95:419-428 